\title{
ATTITUDES TOWARDS SEXUALITY IN SONG OF SONGS AND IN THE CORPUS PAULINUM: A COMPARISON
}

\section{Dirk van der Merwe}

\author{
University of South Africa \\ E-mail: dirkvdm7@gmail.com
}

(Received 19/04/2016; accepted 19/08/2016)

\begin{abstract}
Throughout history Song of Songs has been read and interpreted from various perspectives. Popular and academic Jewish and Christian publications allegorise and metaphorise the meaning of the words and images in Song of Songs. The focus of this research is on a literary-didactic reading as proposed by Turner, which seems to be the most obvious interpretation of Song of Songs. The research on the sexuality perspective communicated in the Song is then compared with the Pauline attitude to sex and marriage in order to find out whether Paul's attitude to sex differs from or corresponds with what we find in Song of Songs. The corpus Paulinum and Song of Songs should both be read with their cultural contexts in mind. While Song of Songs focuses on the erotic love between two lovers, the corpus Paulinum focuses on sexual immorality.
\end{abstract}

\section{INTRODUCTION}

For many years preachers have shied away from preaching ${ }^{1}$ on Song of Songs. ${ }^{2}$ I have never heard any sermon preached on the Song, nor did I ever preach on it. This could perhaps be ascribed to preachers' poor understanding of the text of the amazing "Song", or a hesitance to preach about it because of its erotic connotations. ${ }^{3}$ Owing to

1 Schweitzer $(2008: 16 ; 2010: 3)$ points out that Song of Songs was favoured by Christians "especially monks and mystics - from the early church until the early modern period". During the Middle Ages nearly 30 commentaries were written (DeClaissé-Walford 2008:396). They allegorised the erotic nature of the text to express the love between God and the church or between God and the individual Christian believer. More recently biblical scholars moved away from allegorisation to a historic-critical reading. The Song is now perceived as a love song between two lovers (cf. Exum 1973:79). As the result of this perception Song of Songs lost its attraction (Schweitzer 2008:16).

2 Hereafter referred to as "the Song".

3 Schweitzer (2008:16) writes that Jews and Christians avoided Song of Songs "when they were asked to read this poetry as dealing with real people in sexual situations". Carr (2003:139-51) provides more details. 
the descriptions of physical intimacy in the Song, a typical Jewish boy was not allowed to read it before the age of 13 (Vinatieri 2014:2). Then there was, and still is, the thought of a possible discrepancy between the Song and Paul's attitude to sex. A question often raised is: "Do Paul's statements about sex and marriage, especially 1 Corinthians 5 to 7 , contradict the message about erotic love in the Song?"4

In this article, I cast some light on this issue which has never been done so comprehensively. In the first part of the article the focus is on the attitude towards sexuality in the Song. The second part investigates the attitude towards sexuality in the corpus Paulinum. The article closes with a comparison of these two investigations.

The term "attitudes" in the title of this research article indicates "ways of thinking and feeling", "the ways Paul and the poet of the Song think and feel about sexuality" in an evaluative way. ${ }^{5}$

\section{THE ATTITUDE TO SEXUALITY IN SONG OF SONGS Interpreting Song of Songs: a literal interpretation}

Throughout history the Song has been understood and interpreted in a variety of ways. ${ }^{6}$ Currently, more scholars opt for a literary interpretation. ${ }^{7}$ DeClaissé-Walford (2008:392) refers to the Song as Hebrew poetry. Exum (2005:1; also Boersma 2011:80) describes the Song as "a long lyric poem about erotic love and sexual desire ${ }^{8}$ - a poem in which the body is both object of desire and source of delight". Consequently, more attention has recently been paid to a literary reading of the text ${ }^{9}$

4 The present author is a New Testament scholar who was asked to read a paper comparing sexuality in Song of Songs with the Pauline view of sexuality at the fourth international conference in the Shir ha-Shirim conference series, in Vienna during 2014.

5 See "attitude" at Merriam-Webster.com (http://www.merriam-webster.com; accessed 20/05/2014), and Dictionary.com (http://dictionary.reference.com/browse/attitude; accessed 20/05/2014).

6 See the research done on the various interpretations: Fields (1980:221-31); Garrett (1993:352-366); Tanner (1997a:23-46); and Ndoga and Viviers (2000:1290-1294).

7 See Brenner (1989), Tanner (1997), Exum (2005), Boersma (2011), to name but a few.

8 Brenner (1993:269) points out that different kinds of love occur in the Song: "Serious as well as light-hearted and humorous; different models of human love are drawn upon."

9 Four variations on this approach have been developed. See Tanner (1997a:40-43) for a 
(cf. Gollwitzer 1979; Tanner 1997a:39; Fields 1980:221-31; DeClaissé-Walford 2008:392). ${ }^{10}$

\section{A collection of love poems}

Brenner (1993:269) states that there is not a "single loving pair" in the Song, but rather a number of them. ${ }^{11}$ The interpretation of DeClaissé-Walford (2008:392) complements that of Brenner, who reads the Song as Hebrew poetry and consequently as a collection of love poems. ${ }^{12}$ As a result we are dealing in the Song with different pairs of lovers. She points out that "different models of human love are drawn upon", which consequently accommodate a wider group of addressees. For Brenner (1993:269) a "system of concealed meanings cannot entirely and perhaps should not be ruled out; however, such a system belongs to the readerly act rather than to the (text) level of (written) speech acts". With this she refers to the monologues and dialogues predominant in the Song.

In some songs the power of love and sex, and the enjoyment of love and sex $(2: 2-$ $13 ; 3: 6-5: 1 ; 7: 1-13 ; 8: 5 b-7)$, are accentuated, whereas others $(3: 1-4 ; 5: 2-7 ; 8: 1-4)$ "express disappointments and frustrations that often attend the adolescent search for love and physical intimacy" (Sparks 2008:284). This is probably why there are references to young women ("daughters of Jerusalem") who are exhorted to "not stir up or awaken love until it is ready" (8:4). These exhortations are verified by texts where the woman herself announces that she is a wall $(8: 9)$ or that she protects her own vineyard $(8: 12){ }^{13}$

discussion of this literal view as "a lyric expression of human love", "the seeking and finding fulfilment in love" and "an anthology". For "anthology of love" see also Ewald (1826:9).

10 See also the discourse embedded in the structure of the Song (Linnemeyer 2014:1-23; Exum 1973:47-79).

11 In this research the singular form will be used to simplify the discussion about the lovers.

12 This is supported by Longman (2001:48-49); Murphy (1979:436-443); and Fox (1985) who acknowledges that the Song originally consists of a diversity of poems and an editorial unity of these poems (see also Sparks 2008:278, 284). See also Exum (1973:79; 2005:3741).

13 This clause is ambiguous. Its interpretation depends on who is speaking (Ogden-Zogbo 1998:243). Scholars differ here to whom the speaker in the text is. For Exum $(2005: 259$ - 


\section{Diverse teachings on sexuality}

The Song is about numerous interactions between different couples. It closes as it starts, with a celebration of love and sexuality (cf. 1:2-4; 8:14) (Sparks 2008:292; also Ogden and Zogbo 1998:248): "Let him kiss me with the kisses of his mouth, for your love is better than wine" (1:2), "The king has brought me into his chambers" (1:4) and "Make haste, my beloved" (8:4). In the Song there are numerous references and allusions to sex (e.g., 2:3-17; 4:10-5:1; 5:2-6; 7:1-13). ${ }^{14}$ The two lovers praise each other's physicality. They use ample metaphors and similes to describe each other's body parts and appearance. The Song seems to focus on the physical in its descriptions of romantic and erotic love between a man and a woman. All the human senses are included. A variety of metaphors are used to describe "various actions relating to sexual arousal" (Vinatieri 2014:2). ${ }^{15}$ The woman speaks metaphorically about the sexual arousal of her lover (5:2), and the lover speaks about her genitals using the metaphor of a garden $(4: 11-15 ; 5: 1)$. The woman most often mentions "orgasm and sexual penetration" (3:1-4; 4:16; 5:3-8; 7:10-8:4; Schweitzer 2008:16). ${ }^{16}$

$61)$ it is a man and for Garrett (1993:365) it is the woman. Due to this uncertain ambiguity this author do not want to become involved in this debate and opt that it is the woman who speaks here. See 8:10 where she speaks about her breasts.

14 Bergant (1996:25) refers to the "general agreement about the erotic nature" of Song of Songs among scholars. See Murphy (2014) for a list of sexual symbols in the Song. Boer (2000:296-7) goes so far as to refer to Song of Songs as a "carnal allegory" and "a vast sexual allegory". He states that "the text provides numerous metaphorical descriptions of and allusions to various sex acts". For him "the song spills out a whole vocabulary of sex ... kids (1:8), lie down (1:7), embrace $(2: 6 ; 8: 2)$, hold $(3: 4)$, hold captive $(7: 6 / 5)$, stir up $(2: 7 ; 3: 5 ; 8: 4)$, awaken love $(2: 7 ; 3: 5 ; 8: 4)$, come $(2: 8 ; 4: 16 ; 5: 1)$, come up $(3: 6 ; 4: 2 ; 8: 5)$, arise $(2: 10,13)$, lead and bring $(8: 2)$, knock $(5: 2)$, open $(5: 2,5,6 ; 7: 13 / 12)$, bud and bloom $(7: 13 / 12)$, gather lilies $(6: 2)$, give forth fragrance $(1: 12)$, be sweet to my taste $(2: 3)$, feed $(2: 16 ; 4: 5)$, eat fruit $(4: 16$; see also $5: 1)$, pour out $(1: 3)$, bathe feet $(5: 3)$, and thrust a hand into a hole (5:3)". In my opinion, Boer (2000:297) goes too far. I cannot agree with his perverse interpretation of some texts and seeing the Song as a "poetic porn text". This clearly shows that he does not understand the functions of these metaphors or the portrayal of sex as beauty and enjoyment. See Vinatieri (2014); cf. also Young (2001:80-96).

15 According to Vinatieri (2014:2) the author incorporates "various Oriental euphemisms and double entendres".

16 Song of Songs is "filled with language of sensuality, longing, intimacy, playfulness, and human affection" (DeClaissé-Walford 2008:392). Consult Vinatieri (2014) for more symbols and their meaning in the rest of the Song. For more complete explanations of the meanings of these symbols, consult the commentaries of Ogden and Zogbo (1998) and 
This sexually oriented woman is zealous and enjoys intimacy with her lover, an intimacy which is a physical connection as well as an emotional and interpersonal bond. She refers to her lover with the words "This is my beloved and this is my friend" (5:16), and expresses her desire to be a seal upon his heart and a seal upon his arm (8:6). The Song portrays a "positive sexually confident woman". She ruins the classifications of ancient and conventional dichotomies which "classify all women as either virgins or whores" (Schweitzer 2008:16-7; 2010:3).

Besides this literary view, Tanner (1997a:44) incorporates another perspective in his view of the Song. ${ }^{17}$ According to him the Song has two layers: (1) "with its expressions of romantic and sexual bliss..." and (2) it seems also "to communicate a lesson on love that goes even deeper". ${ }^{19}$ This implies that the Song has to be understood and interpreted as both literary and didactic. On the literary level, the lovers are used as characters to address the topic of the romantic and erotic experience $^{20}$ (Tanner 1997a:46; see also Vinatieri 2014:2; Robinson 2004:12). On the didactic level the following critical aspect is stressed: ${ }^{21}$ not to "stir up or awaken (erotic) love until it is ready" (8:4). If erotic love is stirred up or awakened before it is ready, disappointments and frustrations might follow. When a person has reached maturity and is ready, then erotic love might become a most wonderful and enjoyable experience.

At the end of the Song (8:10), a marriageable and mature woman is described; she is now ready for a sexual relationship. In the last chapter the woman delivers "a lesson of love and its jealousy" (Tanner 1997a:46; see also Garrett 1993:379). This is a different women; she is not the one involved in sexual activities referred to earlier. Although her "breasts are like towers", she informs the readers that when she was

Garrett (1993).

17 See also Tanner's (1997b:142-161) discussion "The message of the Song of Songs".

18 Tanner adds "in marriage".

19 Sparks (2008:278) interprets Song of Songs as "a collection of love songs edited to teach young Jewish women propriety in matters of love and sex". See also Schweitzer (2008:17).

20 Schweitzer $(2008: 16$; 2010:2) refers to Song of Songs as containing "erotic love poems". Tanner (1997a:44; cf. also Schweitzer 2008:16-17) interprets this as romantic and sexual experience within the marriage environment.

21 According to Tanner (1997a:46) the two elements stressed are fidelity and devotion. 
confronted with sex she stood as "a wall". She recapitulates her evidence in referring to the vineyard metaphor that follows in 8:11-12 (Sparks 2008:290). Then there is also the critical point in the text where her brothers wish to protect the reputation of their sister, probably her virginity (see Fox 1985:171-73, referred to by Sparks 2008:290). For them it is obvious that sexual temptations will come their young sister's way as she goes through adolescence. The question they wrestle with (Tanner 1997b:143) is whether their young sister would keep herself sexually pure until she "is ready" for this kind of love. Their question is whether their sister would become a "wall" or a "door" when faced with temptation. The "wall" and the "door" metaphors refer to different paths she might pursue en route to maturity. The "wall" suggests a boundary and fence that prohibit admission into her sexual life. The "door", on the other hand, gives access to others (Tanner 1997b:144).

The brothers, who act as the guardians of family honour, hope to see their young sister become a "wall" en route to maturity. This means that she would keep herself virtuous and resist any sexual advances by men who would court her. If she becomes a "door" (if she yields to men), her brothers will have to protect and fence her. They have to make sure that no situation develops where she could easily allow her desires of the moment to take command of her (Tanner 1997b:144).

Song 8:12 refers to the young woman's purity in love and sex. She has not been immoral with "her vineyard"; she has preserved it for her one and only "lover". As an undefiled woman, she brings happiness" (שָָׁלוֹם) to her lover (8:10) and encourages him sexually with the words: "Make haste, my beloved, / and be like a gazelle / or a young stag / upon the mountains of spices" (8:14). The Song periodically advises young women ("daughters of Jerusalem") to protect themselves against the dangers of hasty love and sex. Finally, it concludes (Sparks 2008:291) on a positive note, looking forward to the moment of having sex when love is ready (8:4).

The description of the young woman depicted in 8:8-9 stands in contrast to her depiction in 8:10. Here the woman is viewed as more mature. She says the following about herself: "I was a wall, and my breasts were like towers; then I was in his eyes as one who brings peace." She has developed from having "no breasts" to 
having "breasts like towers" - she has become sexually mature and can unequivocally say to her brothers, "I was a wall." This implies that she has kept herself morally pure (Tanner 1997:144) until she has been ready for sex.

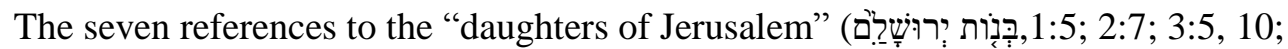
$5: 8,16 ; 8: 4)$ in the Song complement the exhortation to resist any sexual advances. Her message to these women is not to arouse love itself $(2: 7 ; 3: 5 ; 8: 4)$. These young women should not allow themselves to be sexually aroused until the proper time and the right person arrives. For the poet the natural joy of sexual awakening is ruined by any form of premature experimentation. Thus she instructs the "daughters of Jerusalem" with reference to a deer and a gazelle: for a woman to awaken love prematurely would be to rob herself of the full experience of romance and sexuality, symbolised by these graceful animals (Sparks 2008:284).

In conclusion, it is evident that there are various love stories and contrasting portraits of love in the Song. The Song is a compilation of love poems. The consequence is "diverse impressions and implications" (Sparks 2008:284). Some of these poems underscore sex and the power of love $(2: 3-13 ; 3: 6-5: 1 ; 7: 1-13 ; 8: 5 b-7)$, while others $(3: 1-4 ; 5: 2-7 ; 8: 1-4)$ describe the "disappointments and frustrations" that are often encountered in the quest for "love and physical intimacy" (Sparks 2008:284).

\section{Erotic love in Song of Songs}

Insights into the nature of erotic love, according to the Song, include the following:

1) Sexuality is egalitarian

Lovers are presented as equals in every way: "My beloved is mine and I am his" $(2: 16 ; 6: 3$; cf. $7: 10)$. The poet acknowledges the mutuality of love (Garrett 1993:380).

2) Sexuality is related to wholeness

Physical closeness is important. The lovers speak and cling to each other: he "lies between my breasts" (1:13), "his left hand was under my head, and that his right hand embraced me!" $(2: 6 ; 8: 3)$. According to the Song, sexuality includes mental unity (fantasies) and physical unity between the lovers. All the human senses are 
incorporated in the description of sexuality. The poet uses the five human senses ${ }^{22}$ to describe reality and to stimulate "lived experiences" in the fantasies of the lovers as well as the readers.

3) Sexuality is pleasurable

The poet is concerned with the pleasure of erotic love (cf. McCurley 1983:101). The Song depicts or presents sex as pleasurable, beautiful and good (Davidson 1989:8-16). The description of the bodies in the wasfs complement this statement. The Song celebrates not only the beauty of the human body (Robinson 2004:12), but also the "wholesome beauty and enjoyment" of human sexual love (Davidson 1989:17; also Garrett 1993:16).

4) Sex is more than physical intimacy

Sex "stretches beyond intercourse" (Schweitzer 2008:17). The Song offers the perspective that intercourse is only one aspect of making love. Therefore, love is more than knowing the body of the other person - it is also the getting to know the heart of the other person. ${ }^{23}$ The Song is passionate; it describes physical love and also the quest for intimacy beyond intercourse (Schweitzer 2008:17). The Song offers the perspective that intercourse is only one factor among many that contribute to authentic sexuality. The text "describes yearning for and celebration of lovemaking ..." (Carr 2003:115).

5) Sexuality and maturity

(Erotic) Love should not be stirred up or awakened prematurely $(2: 7 ; 8: 4)$.

6) Sexuality, procreation and marriage

The references to erotic love are nowhere connected to marriage or procreation (Schweitzer 2010:3). Very little in the book suggests that the two lovers are married (see also Schweitzer 2008:13-24; 2010:1-9; Hess 2005:n.p.), although the word "bride" appears six times (4:8-5:1).

22 There are references to all the senses in the Song: sight $(1: 6,9 ; 2: 14 ; 4: 9 ; 5: 5 ; 7: 1-6)$; hearing $(2: 14 ; 5: 2 ; 8: 13)$; touch $(1: 2 ; 2: 4,6 ; 7: 9)$; taste $(2: 3 ; 4: 16 ; 7: 9 ; 8: 3)$; smell $(1: 3$; 7:13).

23 Robinson (2004:12) points out that sexual intimacy is usually described in Scripture as "to know" the other person. 


\section{7) Sexual fantasies}

The Song is saturated with the sexual fantasies of the lovers, which stimulate the sexual fantasies of the readers. In these fantasies beauty, different places where the lovers meet, senses, emotion and details about body parts play necessary roles. ${ }^{24}$

\section{THE ATTITUDE TO SEXUALITY IN THE CORPUS PAULINUM ${ }^{25}$ Paul's background: who is Paul?}

The apostle Paul belonged to three different worlds. He was simultaneously a Roman citizen, a Hellenistic Jew and a Jewish scribe. The Hellenistic Jews were famous for their faith in God and their pure morals. Through his training in Jerusalem, Paul also had contact with the body of scribes there (Dibelius 1953:15).

Paul was not married. He lived alone out of conviction (cf. 1 Cor 7:1, 8; 9:5). Like the Stoic philosopher Epictetus, Paul most likely feared that marriage or family life would hamper his service to humanity (and also to God). He believed that this was his calling (Schnelle 2003:59; see also Newman and Nida 1973:138).

Schnelle (2003:69) points out that Jerusalem was the natural centre for Pharisees to receive their education (cf. Hengel 1992:29-34, 38-39). If Paul completed his Toraic studies under Gamaliel I, he most likely came to Jerusalem when he was 15 years of age (Schnelle 2003:69). All this information implies that Paul had a good Jewish theological (Old Testament) education. ${ }^{26}$

At the time when Paul (50-63 C.E.) wrote his epistles, the $\mathrm{LXX}^{27}$ which he used would have reached a fixed and completed form ${ }^{28}$ or volume. This implies that Paul

24 See Van der Merwe (forthcoming) for a more detailed investigation of sexuality in Song of Songs.

25 Sexuality in the corpus Paulinum is more complex than what we find in Song of Songs. Paul addresses a variety of sexual aspects which have to be interpreted from specific situations. This leads to an unbalanced volume of discussion.

26 See Du Toit (1984:34) with regard to the chronology of Paul's life.

27 See Wolf (1948:331-338); Jobes (2000); and Hengel (2002). See also Schnelle (2003:108111) for a lengthy discussion on how Paul uses the LXX (Septuagint) in his writings.

28 The author is aware that the LXX translation was done over several decades and that Song of Songs was one of those books that received canonical status at a late stage. Cf. Davidson (1989:1-19); also Tanner (1997b:161) and Schweitzer (2008:17). 
knew or at least had taken cognisance of Song of Songs. He also would have known what the Old Testament (in particular the Pentateuch and the prophets) teaches about sex and marriage. ${ }^{29}$

In my discussion of Paul's view of sex and marriage I will concentrate primarily on his first epistle written to the Corinthians, and secondarily on his epistles written to the Romans and his first epistle to the Thessalonians. Paul addresses more aspects of sexuality than in the case of Song of Songs and therefore needs more attention.

\section{The epistles of Paul: thoughts about sexual conduct and marriage}

Paul expresses his views on sexuality within his contemporary cultural context. The consideration of this is critically important to an understanding of Paul's view of sex. Sometimes Paul alludes to conventional wisdom and practices, and sometimes he rejects them. Three additional factors to be considered here are Paul's holistic view of a person, his apocalyptic discernment of the imminent return of Christ and his immense desire to create orderly Christian communities (Schweitzer 2008:21). Paul writes extensively about issues that relate to sexuality, but not about sexuality itself. Paul appeals for holiness among believers and rejects "fornication" or "sexual

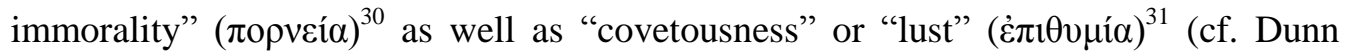
2003:120). Unfortunately he does not elaborate much on these issues (1 Thess 4:3-8).

29 See Dunn (2003) for excellent references to how Paul, in his theology, is embedded in Jewish thought and tradition.

30 Louw and Nida (1996:770) define fornication or sexual immorality as "to engage in sexual immorality of any kind, often with the implication of prostitution - to engage in illicit sex, to commit fornication, sexual immorality, prostitution". Danker (2000:854) calls it "unlawful sexual intercourse, prostitution, unchastity, fornication". Freiberg, Freiberg and Miller (2000:323) describe it as "generally, of every kind of extramarital, unlawful, or unnatural sexual intercourse fornication, sexual immorality, prostitution". Balz and Schneider (1990:137) calls it "sexual immorality".

31 Danker (2000:372) defines covetousness or lust as "a desire for someth[ing] forbidden or simply inordinate, craving, lust". Louw and Nida (1996:290) say covetous or lust means "to strongly desire to have what belongs to someone else and/or to engage in an activity which is morally wrong - 'to covet, to lust, evil desires, lust, desire"”. Freiberg, Freiberg and Miller (2000:164) say the terms are used "in a bad sense of unrestrained desire for something forbidden - lust, craving, evil desire". 
Paul refers to these two issues briefly in 1 Thessalonians 4:4-5 and Romans 1:24. These texts will now be discussed.

\section{Living between two worlds: sexual conduct}

\section{Romans 1:24 (sex not to be abused)}

In Romans 1:24 Paul describes the moral decadence in the Christian community in Rome. It is the consequence of their rejection of God and the ensuing worship of idols (Newman and Nida 1973:26). It reads: "Therefore God gave them up in the lusts

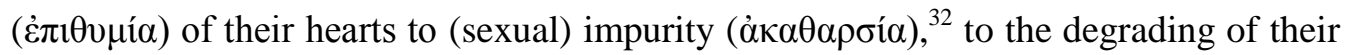
bodies among themselves." Paul labels the immediate manifestation of $\sin$ as $\dot{\varepsilon} \pi \imath \theta u$ í $^{\prime}$ (lusts, Romans 1:24) ${ }^{33}$ which is the result of rejecting (dishonouring) God (Schreiner 1998:92). He uses this noun in two ways, namely to denote desire/eagerness ("with great eagerness to see you face to face" [1 Thess. 2:17] and "my desire is to depart and be with Christ" [Phil 1:23]); but also to denote immoral desires ("as a desire for something forbidden, 'covetousness' or 'lust'” [Dunn 2003:120]). Paul also frequently speaks of the desires of the flesh in a negative way. ${ }^{34}$ What he is actually referring to is a habitual life lived in terms of satisfying one's natural or animal desires as one's primary purpose. He uses this term to describe sin as that power which transforms $\dot{\varepsilon} \pi \imath \theta u \mu$ ía from something neutral or positive to something harmful - from "virtuous desire" to "lust" or "destructive self-indulgence" (Dunn 2003:120; also Mounce 1995:81). ${ }^{35}$

32 Freiberg, Freiberg and Miller (2000:39) define impurity as "literally worthless material, waste; of graves decayed flesh, causing ceremonial uncleanness, defilement (MT 23.27);

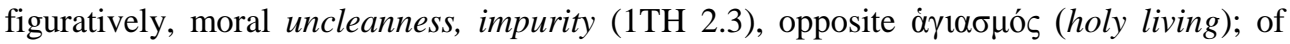
sexual vice immorality, indecency, sexual impurity (RO 1.24)". Louw and Nida (1996:769) says the term is used for "the state of moral impurity, especially in relationship to sexual sin - 'impurity, immorality, filthiness"'. According to Danker (2000:34) it denotes "a state of moral corruption ... immorality, vileness esp. of sexual sins". See also Balz and Schneider (1990:48).

33 Paul uses this noun 19 times in his epistles: Romans 1:24; 6:12; 7:7, 8; 13:14; Galatians 5:16, 24; Ephesians 2:3; 4:22; Philippians 1:23; Colossians 3:5; 1 Thessalonians 2:17; 4:5; 1 Timothy 6:9; 2 Timothy 2:22; $3: 6 ; 4: 3$; Titus $2: 12 ; 3: 3$.

34 Romans 13:14; Galatians 5:16, 24; also Romans 6:12; Ephesians 2:3, cf. 1 Thessalonians 4:5.

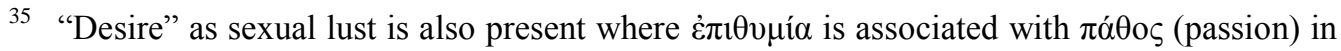


Dunn interprets this sexual activity as one of the most characteristic expressions of self-indulgent desire. According to Dunn, Paul expresses this clearly by using the noun $\dot{\alpha} \kappa \alpha \theta \alpha \rho \sigma i ́ \alpha$ (impurity) to denote sexual immorality (cf. 2 Cor 12:21; Gal 5:19; Eph 5:3; Col 3:5). Even the phrase "degrading of their bodies among themselves" (Rom 1:24) refers to disrespectful sexual activities (2003:121). Paul's unyielding hostility towards $\pi$ opveía (unlawful sexual intercourse, Danker 2000:854) ${ }^{36}$ does not imply that he was negative or hostile to sexual affairs. He criticised the misuse of sex. ${ }^{37}$ Such conduct distinguished Christians from religious cults as well as the "broader ethos of the day". With this attitude Paul stood solidly within the Jewish tradition, as is evident from Romans 1:24-27 (Dunn 2003:690).

\section{Thessalonians 4:4-5 (sex without lust)}

Here I argue that in 1 Thessalonians 4:4-5 Paul accepts the philosophical notion of his

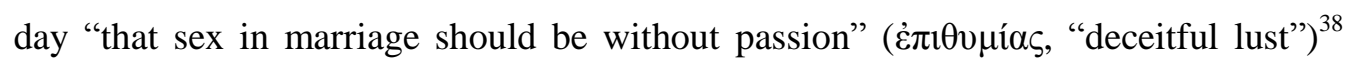
(cf. Fredrickson 2003:23). In 1 Thessalonians 4:3-5 Paul writes, (3) "For this is the

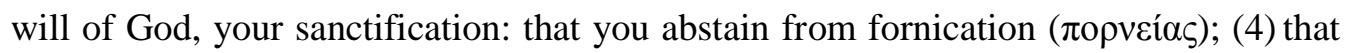
each one of you know how to take a wife for himself [control your own body, NRSV] in holiness and honor, (5) not with lustful passion ( $\left.\pi \dot{\alpha} \theta \varepsilon \iota \dot{\varepsilon} \pi \imath \theta \mu \mu_{1} \alpha \varsigma\right)$ like the Gentiles

both 1 Thessalonians 4:5 and Colossians 3:5. See also Schweitzer's (2008:20 ff.) discussion of Paul's view of homosexuality.

36 Cf. the response of Jensen (1978:161-184) to Malina's (1972:10-17) .

37 Such abuse covered in particular any form of sexual immorality.

38 According to Zodhiates (2000:\#1939), " $\dot{\varepsilon} \pi \imath \theta u \mu$ í $\alpha$ refers to desiring greatly, strong desire, longing, lust. (a) Generally longing (Luke 22:15; Phil. 1:23; 1 Thess. 2:17; Rev. 18:14. (b) More frequently in a bad sense, irregular and inordinate desire, appetite, lust. - Generally (Mark 4:19; Rom. 6:12; 7:7, 8; 13:14, "for its lusts" [a.t.], i.e., to satisfy the carnal appetites; Col. 3:5; 1 Tim. 6:9; 2 Tim. 3:6; 4:3; Titus 3:3; James 1:14, 15; 1 Pet. 1:14; 4:2, $3 ; 2$ Pet. 1:4; 3:3; Jude 1:16, 18). The lust of the flesh means carnal desires, appetites (Gal. 5:16, 24; Eph. 2:3; 2 Pet. 2:18; 1 John 2:16). Also epithumíai sarkikaí (4559), carnal, fleshly (1 Pet. 2:11) referring to worldly desires; desires of the eyes (1 John 2:16); polluted desires (2 Pet. 2:10); "lusts of deceit" (a.t.) means "deceitful lusts" (Eph. 4:22); "youthful lusts" (2 Tim. 2:22). All these refer to the desires which are fixed on sensual objects as pleasures, profits, honours. - Spoken of impure desire, lewdness (Rom. 1:24; 1 Thess. 4:5). - By metonymy, lust, i.e., an object of impure desire, that which is lusted after (John 8:44; 1 John 2:17.” 
who do not know God." The term $\sigma \kappa \varepsilon v \tilde{0}$ s is translated here in 4:4 as "wife" 39 with the connotation of being a vessel of her husband. ${ }^{40}$ This metaphor may seem shocking to us today, but it was widely used in ancient literature, for example by Aristotle and Clement of Alexandria. This makes a strong case that Paul refers to "wife" in 4:4 (Fredrickson 2003:24). According to Foucault (1985:141-184, quoted by Frederickson 2003:25) "the ancient science of household management was the background for conceptualising the wife as possession of the husband". The obligation that this taxonomy generated for the male was "to possess and use his wife properly" (Fredrickson 2003:25). This implies, according to Fredrickson (2003:25), that the "proper possessing of the wife" compels the husband to avoid lust. This information shows that the language Paul uses to write about sex and marriage in 1 Thessalonians 4:4-5 overlaps with ancient philosophical discourse (Fredrickson 2003:25).

Therefore Paul's exhortation about how the wife should be possessed implies sex without lust. This exhortation echoes those of many ancient ethicists, ${ }^{41}$ who advocated sex without passion as an ideal feature of marriage (cf. 1 Cor 7:9). Paul refers here to the uncontrolled character of love as well as a disgraceful lack of self-control ( $\dot{\pi} \pi \theta 0 \mu$ í $\alpha$ ), which is associated with the key philosophical term "passion/lust" ( $\pi \dot{\alpha} \theta$ os).

In 1 Thessalonians 4:5 Paul, like some ancient authors, condemns desire or lust $\left(\dot{\varepsilon} \pi \imath v \mu \mu^{\prime} \alpha\right)$ in sex, even within the milieu of marriage, because it is unnatural. For Paul (and significant numbers of ancient thinkers) sexual desire is voracious; it is against nature (Fredrickson 2003:29-30). This implies that sexual immorality should be avoided. According to Green (2002:190) this language relates to traditional Jewish language (see T. Levi 9:9-10; Tob. 4:12).

39 This noun, "wife", is interpreted and translated by Danker (2000:927) as "a human being exercising a function, instrument, vessel" (original emphasis); see also Fredrickson (2003:24). The actual Greek noun for wife is yoví.

40 Wanamaker (1990:152) argues against the translation of $\sigma \kappa \varepsilon \tilde{0} \mathrm{\zeta}$ as wife. He refers to Rigaux (1956:504-506), Morris (1991:123f.), Marxsen (1979:60f.), Bruce (1982:83), and

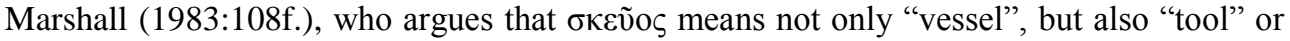
"implement".

41 Consult Fredrickson (2003:26) for examples. 


\section{Corinthians 5:1-5 (the body is irrelevant)}

In the first three chapters it becomes clear that the Corinthians claimed to have spiritual superiority. Some of them accepted the Hellenistic view that everything spiritual was good and everything physical was evil. ${ }^{42}$ Therefore they would say, "The body is irrelevant, so I can do whatever I want" (Schweitzer 2008:19; also cf. Molvaer

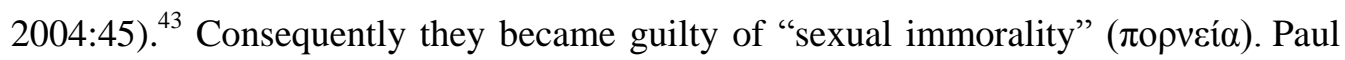
refers to that sexual immorality in 5:1 as "a kind that is not found even among pagans". He refers to "a man [who] is living with his father's wife" (in Jewish circles: stepmother, Kistemaker and Hendriksen 2001:156). Paul pronounces "judgment in the name of the Lord Jesus on the man who has done such a thing" (5:3-4) and warns the church that the person "would have been removed from among you" (5:2; also cf. 5:13). Paul's ethical concerns are clear: if such conduct is not condemned it invites a general corruption of standards. Owing to the interdependence of the body of Christ, the spiritual health of the congregation is at stake (5:6-8) (Dunn 2003:691).

\section{Corinthians 6:12-20 (sexual immorality - prostitution)}

1 Corinthians describes a situation where the boundaries between the church and the world were by no means clear. This became evident when some ethical issues arose in the Corinthian church. Some of the new converts still shared many of the moral values of their surrounding society. They were now caught between the incompatible values of society and church. ${ }^{44}$ Some of these new members were involved in prostitution they retained their former sexual values $(6: 11)$ and pleasures $(6: 12)^{45}$ even after they had converted to Christianity and become part of the Corinthian church.

42 This is a typical point of view put forward by Plato and was also believed by the Gnostics .

43 Paul's discussion of the resurrected body is different (Molvaer 2004:45).

44 According to Dunn $(2003: 690)$ these differences are best seen when 1 Corinthians $8-10$ is compared with Romans 14:1-15:6.

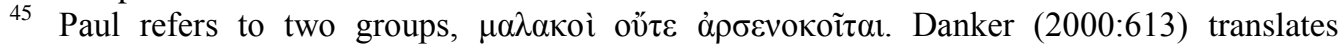

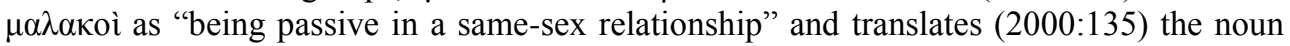

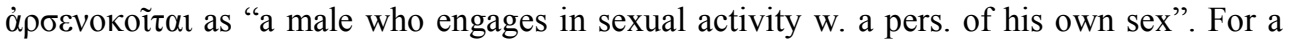
discussion of this verse (6:9) and terminology, see Collins (2000:86-92). For some scholars these terms do not refer to homosexual actions in general, but to sexual activities of older men with younger boys (pederasty), which was common among the Hellenistic upper class (Collins 2000:90-92; Schweitzer 2008:19). 
Paul's appeal to the church to address the issue of sexual conduct is apparent in this discourse (cf. Dunn 2003:690). Paul now reprimands them, ${ }^{16,}$ 'Do you not know that whoever is united to a prostitute becomes one body with her.... The two shall be one flesh." According to Garland (2003:233) this means that sexual intercourse does not only join two people's bodies, it also joins their spirits.

Paul's concern is that "sexual immorality" ( $\pi$ o $\rho v \varepsilon i ́ \alpha v)$ poses a constant danger to

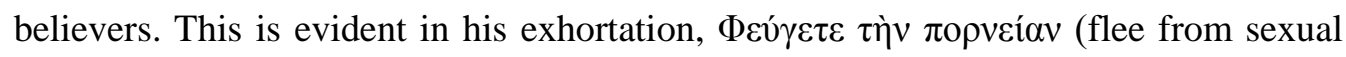
immortality, 6:18) (Dunn 2003:121). Paul is uncompromising about sexual immorality: it is totally unacceptable in Christianity (Dunn 2003:692).

\section{Corinthians 7 (lack of self-control)}

In 1 Corinthians 7 Paul addresses another concern about sexuality, namely selfcontrol. In contrast to Hellenistic and conventional Jewish thought of the time, Paul elevates the status of women within marriage. He also confirms that sex is not a sin. In the same chapter Paul also communicates two additional views: celibacy should be the preferred choice for both men and women owing to the imminent parousia of Jesus; and marriage should function as the "context for sexual release, in particular for those who lack self-control" (Schweitzer 2008:20). In 1 Corinthians 7:9 Paul shows a realistic appreciation of sexual desires: "But if they are not practicing self-control, they should marry. For it is better to marry than to be inflamed with passion." ${ }^{46}$ Paul asserts that married rights are a mutual responsibility, according to 7:3-4. In the following verse (7:5) he states that enforced abstinence rather than the enjoyment of sex gives Satan scope for temptation. Paul surely complements Song of Songs in recognising the power of the sex drive. If it is not appropriately directed it can weaken the partners and consequently deform relationships and responsibilities (Dunn 2003:121).

461 Corinthians 7:9, 36-38 (a much debated passage in New Testament circles) has to be interpreted in the light of historical circumstances and the problems experienced by Christians newly converted from paganism (Molvaer 2004:45). 


\section{Living between two worlds: sexual relations within marriage (1 Corinthians 7$)^{47}$}

Brown (2008:54) remarks that 1 Corinthians 7 is "the one chapter that was to determine all Christian thought on marriage and celibacy for well over a millennium" (cf. also Dunn 2003:693). Attention will be given to two critical factors that certainly influence the interpretation of this chapter.

The first factor is that Paul responds here to some questions asked by the Corinthians themselves. ${ }^{48}$ According to Dunn (2003:294) this means that he was not trying to formulate or provide a theology of marriage. His argument is that Paul does not refer to the primary purpose of marriage, namely procreation.

What happens here is that Paul discusses marriage in reply to a letter he has received. It is widely agreed that the opening statement of chapter 7:1, "Now

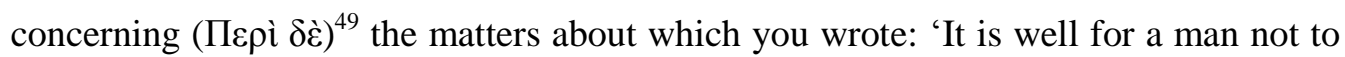

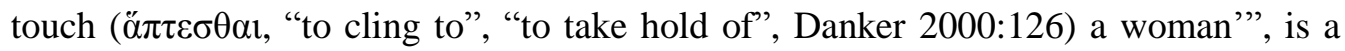
quotation from the letter previously written to him (Thistleton 2000:498). Paul probably adapted his advice to the Corinthians to meet their worldview. His own views were given here. ${ }^{50}$ This could mean that the note of asceticism reflects in particular the views of the Corinthians rather than Paul's own (Dunn 2003:694-5).

The second factor to be considered is that the Corinthian church was still in the

47 In this subsection I rely strongly on the work done by Dunn (2003).

48 This is apparent from Paul's use of the phrase $\pi \varepsilon \rho \grave{~} \delta \dot{\varepsilon}$ ("now concerning...") in $7: 1$ and $7: 25$, which indicates that the letter Paul received from the Corinthians posed a number of questions about marriage (7:1-24) and the virgins and unmarried (7:25-38). Interestingly Paul uses two distinctive nouns repetitively: ö $\gamma \alpha \mu \rho_{\varsigma}$ ("unmarried", 8, 11, 32, 34) and $\pi \alpha \rho \theta \varepsilon \dot{v} o \varsigma$ ("virgin", 25, 28, 34 and 36-38). From this it seems that these are two distinct conditions (Dunn 2003:694). However, according to Dunn (2003:694), $\pi \alpha \rho \theta \varepsilon \dot{v}$ o $\varsigma$ should, in this context, be interpreted not as an "unmarried" woman, but as one who is engaged (cf. $7: 36$ and 38). When Paul encourages the two to marry (7:36) it rules out the idea of a married couple agreeing to live celibate lives (cf. Deming 1995:40-47; Fee 1987:325-27).

49 Garland (2003:249) regards the $\pi \varepsilon \rho \grave{~} \delta \varepsilon$ formula as the introduction of a direct quotation or paraphrase from the letter of the Corinthians. This formula then serves as subject matter of the section about sexual relationships in marriage.

50 This is verified by the following expressions used by Paul: "This I say by way of concession" (7:6); "I wish" (7:7); "I say" (7:8); "I give this command" (7:10); "I say - I and not the Lord" (7:12); "This is my rule" (7:17); "I have no command of the Lord, but I give my opinion" (7:25); "I think" (7:26); "I say this for your own benefit" (7:35). 
process of developing its idiosyncratic Christian character. ${ }^{51}$ The variety of networks and relationships of these people still crossed moral boundaries because they were still based on the worldview of Corinthian society. It was essential for Paul to link his counselling to the real and unyielding difficulties posed to him by the Corinthians (Dunn 2003:695).

In his counselling Paul emphasises the primary importance of a relationship with the Lord $(7: 17,22,32,34-35,39)$. Paul was aware that the congregation found themselves "between the ages" and "between two worlds" (Dunn 2003:695). Therefore, in his response to their questions, he does not hesitate to express his personal views about his situation: being unmarried ${ }^{52}$ enables him to devote himself to the matters of the Lord. He states clearly that these are his subjective "opinions" (see footnote 43), which is without the force of "commands". From Paul's counsel, it is evident that his major concern lies with "priorities and the realism with which they should be pursued" (Dunn 2003:695). It is not his concern to endorse a specific attitude to marriage or marriage relations, or even to promote a strategy for asceticism (Dunn 2003:695). Let us look at the development of his arguments according to the following paragraphs:

\section{First paragraph 7:1-7}

Paul acknowledges in these verses the effects of his own understanding of the dangers

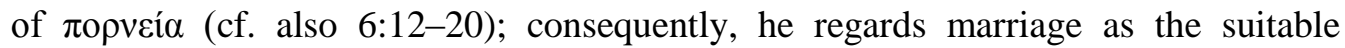
context for sexual activities. Marriage then is the environment where $\dot{\varepsilon} \pi t \theta 0 \mu$ í can

51 This has to be understood against the background of various kinds of problems faced by new converts from paganism (Molvaer 2004:45).

52 Houdman (2014) describes Paul's marital status as follows: no reference about whether Paul was married or not occurs in the New Testament. A text used to prove a possible marital status of Paul is 1 Corinthians 9:5: "Do we not have the right to be accompanied by a wife, as the other apostles and the brothers of the Lord and Cephas?" If Paul had been married at some stage, his wife must have died very early in his life, considering that no reference to her occurs in any of his writings. Contrary to this, Paul declares in 1 Corinthians 7:1-7 that he has the gift of celibacy. It seems that the statement of Paul to the unmarried and widows in the Corinthian church proves his unmarried status at the time of writing this letter: "To the unmarried and the widows I say that it is well for them to remain single as I do. But if they cannot exercise self-control, they should marry. For it is better to marry than to be aflame with passion." It seems clear that Paul was certainly not married at that point in time. Whether or not he married afterward remains speculation. 
remain a positive "desire" and is prevented from subsiding into "lust/passion" (7:2; Dunn 2003:695-6). "Sexual permissiveness" was prevalent in Corinth. Corinthians

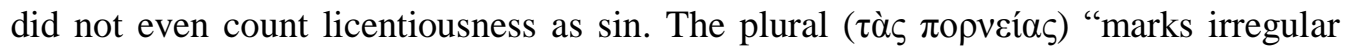
lusts" (Jamieson, Fausset and Brown 1997/II:274).

Paul's notion of marriage is one of real partnership where sexual relations, tàs $\pi$ opveíass, are expected (7:3-4). If devotion (prayer) was to be prioritised at times, and sexual abstinence was required, then it should be by mutual consent only, and the duration of abstinence should be limited (7:5; Dunn 2003:695-6). Husbands and wives should fulfil their marital duty. Husbands should not be demanding, but only fulfil their marital obligations, and wives should give their husbands what they owe them (Kistemaker and Hendriksen 2001:212).

\section{Second paragraph 7:8-16}

In this paragraph Paul applies the same logic to unmarried persons and widows considering (re)marriage. Again Paul suggests that marriage constitutes the appropriate environment for sexual relations (7:8-9). Those caught up in unhappy or failing marriages he refers to the teaching of Jesus, namely that divorce should not be considered (Dunn 2003:696).

\section{Third paragraph 7:17-24}

In order to strengthen the conduct proposed above, Paul reminds the reader that present status (circumcised or uncircumcised, slave or free) does not determine the standing of a person before God (7:17-24). The principle is "obeying the commandments of God" (7:19). The essence here is to have a relationship with Christ (7:22-23) and with God (7:24). Other relationships and identity factors are relative to these crucial matters (Dunn 2003:697).

\section{Fourth paragraph 7:25-38}

In these verses Paul responds to the second set of questions about marriage. Again he follows the same line of thought: marriage can be avowed or the intention of marriage be declined without transgressing (7:27-28). Those who marry "will experience distress in this life" (7:28). Paul does not attempt to promote any ascetic views or practices. For him it is the primacy of the interests of the Lord and not his imminent 
coming "which relativizes (not abolishes or diminishes) all other concerns" (Dunn 2003:697).

The verses of concern in this paragraph are 7:36-38. They are of the most debated verses in the New Testament. Molvaer (2004:45-59) makes an excellent contribution in his interpretation of these verses "against the background of problems arising for new converts from paganism. It also sheds new light in the interpretation of 7:9." This thorough analysis of Molvaer (2004:45) indicates that "Paul discourages but does not disapprove of sex between unmarried couples". "That sex outside marriage for married people (adultery) is prohibited in Christian ethics, we can see from many other passages in OT \& NT. ${ }^{53}$ But in 1 Cor 7:9 \& 36-38, Paul permits sex between partners committed to each other, even if they are unmarried and have not promised each other marriage" (Molvaer 2004:50). ${ }^{54}$

In 1 Corinthians Paul's approach to sexuality is systematic. In 5:1-5 he condemns incest and in 6:12-20 sexual sins. He encourages the converts in Corinth to flee from immorality. In 7:1 he quotes from the letter he received from them, which proposes that all sexual relationships should be avoided. In his reaction to this he points "to God's gracious provision of matrimony" (Kistemaker and Hendriksen 2001:217). From the above discussion it is clear that Paul writes as a deeply caring pastor. $\mathrm{He}$ does not discourage marriage, restrict sexual relations within marriage or even promote any kind of asceticism. He is non-prescriptive (Dunn 2003:698).

\section{A COMPARISON OF PAUL'S ATTITUDE TO SEXUAL RELATIONS AND THE ATTITUDE REVEALED IN SONG OF SONGS \\ Didactic}

Both documents have a didactic character: Paul replies to the Corinthians' questions about sex, while Song of Songs could have been used as a "lovemaking" manual

53 According to the seventh commandment (Ex. 20:14), "You shall not commit adultery" is adultery the violation of the marriage vow (cf. Mt. 5:28).

54 Molvaer (2004:57) points out that probably many commentators will not agree with his interpretation. He refers to the commentary of Thiselton (2000:51-69, 593-602) who discusses almost all the interpretations on these texts in great detail. 
(Vinatieri 2014:2; also cf. Tanner 1997b:142-161). Song of Songs is part of wisdom literature, which primarily functions as didactic literature (LaCoque 2006:41).

\section{Contradiction or complementation?}

Paul and Song of Songs address different aspects of sex. Song of Songs describes fantasies (it is poetry) of the enjoyment of erotic love and each other's bodies, while Paul is more concerned about sexual immorality that could harm people (cf. Schweitzer 2010:22). Paul's Jewish education could be the reason why he does not approve of more relaxed sexual behaviour. He retains a sharp sense of the danger of uncontrolled $\dot{\varepsilon} \pi \mathrm{\imath} \theta u \mu i ́ \alpha$ and $\pi \mathrm{o} \rho v \varepsilon i ́ \alpha$, which can rapidly change from "desire" into "lust",55 (cf. 7:3-5, 7-11).

\section{Relationships and responsibilities}

Both Paul and Song of Songs focus on relationships and responsibilities, Song of Songs within a sexual relationship and Paul within marriage. Paul is cautious. For him marriage is the environment in which sex should actually be enjoyed. In marriage there is no place for sexual immorality. In Song of Songs the woman warns three times: "Do not arouse or awaken love until it is ready" $(2: 7 ; 3: 5 ; 8: 4)$. Unfortunately she never gives more details, so there is no criteria the reader may follow to determine when it is appropriate to awaken love (Schweitzer 2008:17).

\section{Promotion of sexuality}

Carr (2003:115) writes that the text of the Song "describes yearning for and celebration of lovemaking without ever clearly describing the lovemaking itself". It is important to recognise the Song not as foreplay that leads to intercourse (a means to an end); it is rather "a passionate desire to be enjoyed on its own" (Schweitzer 2008:17). The Song promotes sexuality for the sake of both partners, and not for the proper

55 From "erotic" into "sensual". Dictionary.com describes erotic as "arousing or satisfying sexual desire" and sensual as "carnal; fleshly; lacking in moral restraints; lewd or unchaste" (retrieved from http://www.dictionary.com/browse/erotic, accessed date 21/05/2014). 
limitation or control of desire within marriage. For Paul "desire" in marriage must not culminate in "lust/passion".

\section{Sexuality and spirituality}

Both the poet and Paul connect sexuality with spirituality, albeit differently. These two entities are interwoven in each person, in human relationships and in the humandivine relationship (cf. Schweitzer 2008:22). Paul believes God lives in the body of the believer; according to Song of Songs, although no reference to God occurs in the Song, by implication the love of God is experienced in the passionate love of the two lovers for each other. ${ }^{56}$

\section{Praise of sex}

The Song praises sex, Paul does not. Paul's epistles have negative undertones about immoral sex, but no positive assertions about good sex. Paul was constrained by the Jewish convention that prohibited any public conversation about sex.

\section{Procreation and marriage}

Both say nothing about procreation to legitimise sex. In 1 Corinthians Paul writes extensively about the relationship between sex and marriage, while Song of Songs says nothing at all about marriage. Nowhere in the Song are there any indications that any pair of lovers was married. ${ }^{57}$

\section{Pleasure and joy}

The Pauline talk about sex is emotionless (1 Thess 4:4-5), while the Song is a

56 According to 1 John 4:8, 16, "God is love". Barbiero (2011:503) in his commentary on 8:6 writes that the woman seeks that nothing may ever separate the two lovers. He interprets

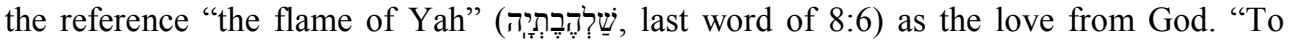
experience love is to experience God" (Barbiero 2011:503). For him this expression refers to the divine nature of love.

57 Unmarried state: in the Song there is no indication that the couples are married. Bergant (1994:28, 33, 37; also Brenner 1993:282) refers to them as "unmarried teenagers"; also see Carr (2000:241); and Sparks (2008:280, 282). 
passionate celebration of the pleasures of sex. Paul (and the NT) lacks interest in aesthetics, pleasure and even the nuanced enjoyment described in the Song.

\section{Both Paul and the Song refer to the human body}

The Song describes fantasies of the enjoyment of each other's beautiful bodies and the pleasure of erotic love. It is a celebration of the joy and desire of intimate love (Garrett 1993:379). Paul refers to the body as the temple of the Spirit and teaches that one

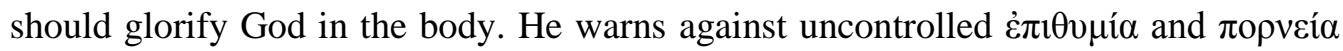
in 1 Corinthians 6. "Do you not know that whoever is united to a prostitute becomes one body with her?" The human body is beautiful, but humans are more than just their bodies. Paul reiterates this by saying that the Spirit lives in the body, therefore it should not be used for sexual immorality (1 Cor 6).

\section{Holistic view}

The poet is fanatic about the physical appearance of the lovers and the quest for intimacy that stretches beyond intercourse - she $^{58}$ promotes sexuality, which she views holistically. This holistic view of sexuality is absent in the corpus Paulinum, which is logical since Paul addresses sexual immorality.

\section{Bipolar objectives}

The Song speaks of two aspects of erotic love: erotic love is joyful and beautiful, but it should not be awoken until a person is ready for it. The Song is a testimony to the beauty and love of God (although not even mentioned in the Song), which are evident in sexual love (cf. Garrett 1993:380). In the corpus Paulinum Paul addresses different sex-related problems: ${ }^{59}$ a lack of self -control, sexual immorality, lust and the abuse of

58 LaCoque (2006:40) argues that this poet was a woman.

59 When we compare the erotic love described in Song of Songs with the rest of the Old Testament it becomes evident that the Song presents an unusual view of sex. The first biblical references to sex noted in Genesis $(2: 24 ; 4: 1 \mathrm{a}, 23 \mathrm{a} ; 9: 20-27 ; 18: 12 ; 19: 8,30-38$; $34 ; 38)$ are merely descriptive. References to sex in the rest of the Pentateuch are singled out for condemnation (cf. Hess 2005:n.p. for references). Even the prophets have little to say about sex. According to Hess (2005:n.p.) lust, adultery and prostitution are topics 
sex. Therefore, the corpus Paulinum (also cf. Proverbs) consists of a number of warnings about the dangers of sexuality, or rather wrong sexuality. Where Paul warns against the negative side of sex, the Song emphasises the positive side of sex.

\section{Equality of women and men in terms of sexuality}

This was very rare in antiquity (Schweitzer 2010:21), but neither the Song nor the corpus Paulinum refers to any form of subordination.

\section{Erotic love between unmarried couples}

Neither Song of Songs nor Paul is against premarital sex. The Song of Songs says erotic love should be enjoyed when the time is ready. Paul discourages sex between unmarried couples, but does not condemn it (Molvaer 2004:45). 1 Corinthians 7:9, 36-38 (a much debated passage in New Testament circles) has to be interpreted in the light of historical circumstances and the problems experienced by Christians newly converted from paganism.

\section{CONCLUSION}

Multiple perspectives on sexuality appear throughout the Bible as is evident from Song of Songs and the corpus Paulinum. It would be unfair to try to harmonise them or even to reduce them to a single point of agreement. This would be doing injustice to

chosen by Jeremiah, Ezekiel and Hosea. Repeatedly they condemn both men and women for their participation in sexual immoralities. Their strongest condemnation is directed against Israel as a nation, which is pictured as a woman who is married to Yahweh but yearns for other lovers - "gods and goddesses other than Yahweh" (cf. Hosea 2:13). In summary, the Pentateuch and the Prophets refer to sex as part of a good creation, though constantly used for wrong purposes. All this creates the impression that sex is described as a terrible thing in the Old Testament. It is a powerful mechanism which "drives people to hurt and kill, to betray and avenge, and to manipulate and demonize". Beyond the basic function of procreation, it seems as if there is nothing good about sex (Hess 2005:n.p.). Fortunately, the Song liberates the Old Testament from this negative view of sex. The Song celebrates physical love, but then within the environment of the committed love relationship. The issues of marriage, procreation or even propriety do not feature in the Song (Hess 2005:n.p.). 
the complexity, authority and truth of biblical texts. Diversity should not always be interpreted negatively; different views "on sexuality should be understood and respected in their different ancient contexts, such as historical, literary, ideological, socio-cultural and theological" (Schweitzer 2010:22).

The Bible asserts that human beings are sexual beings. Their bodies, physicality and sexuality do matter and have value. ${ }^{60}$ Healthy relationships are needed for healthy sexuality - one of the many qualities of human relationships. Thus, "sexuality is not a means to an end but has value on its own" (Schweitzer 2010:3).

\section{BIBLIOGRAPHY}

Balz, H R and Schneider, G 1990. Exegetical dictionary of the New Testament. Grand Rapids: Eerdmans.

Barbiero, G 2011. Song of Songs: a close reading. Tr. M Tait. Supplements to Vetus Testamentum, 144. Leiden: Brill. Available: https://books.google.co.za/books?id=WRDpOELGNdcC\&printsec=frontcover\&dq=Son g+of+Songs:+A+Close+Reading, + Barbiero\&hl=en\&sa=X\&redir_esc=y\#v=onepage\&q $=$ Song $\% 20$ of $\% 20$ Songs $\% 3 \mathrm{~A} \% 20 \mathrm{~A} \% 20 \mathrm{Close} \% 20$ Reading $\% 2 \mathrm{C} \% 20 \mathrm{Barbiero} \& \mathrm{f}=$ false. [Accessed 2016/07/31.]

Bergant, M 1994. "My beloved is mine and I am his" (Song 2:16): The Song of Songs and honor and shame, Semeia 68:23-40.

Boersma, M 2011. Scent in Song: Exploring scented symbols in the Song of Songs, Conversations with the Biblical World XXXI:80-94.

Boer, R 2000. The second coming: repetition and insatiable desire in Song of Songs, Biblical Interpretation 8/3:276-301.

Brenner, A 1989. Song of Songs. Sheffield: JSOT.

1993. To see is to assume: whose love is celebrated in the Song of Songs?, Biblical Interpretation 1/3:267-284.

Brown, P R L 2008. The body and society: men, women, and sexual renunciation in early Christianity. New York: Columbia University Press.

Carr, D M 2003. The erotic word sexuality, spirituality, and the Bible. New York: Oxford University Press.

Collins, R F 2000. Sexual ethics and the New Testament: behaviour and belief. New York: Crossroad Publications.

Danker, F W 2000. Greek-English lexicon of the New Testament and other early Christian literature. Chicago: University of Chicago Press.

Davidson, R M 1989. Theology of sexuality in the Song of Songs: return to Eden, Andrews University Seminary Studies 27/1:1-19.

DeClaissé-Walford, N L 2008. An introduction to the Song of Songs, Review \& Expositor

60 According to Gollwitzer (1979:72) "no one church has done better than another; all have operated under the prejudice of a Neoplatonic hostility to the body and to sex". 
105/3:389-402.

Deming, W 2004. Paul on marriage and celibacy: the Hellenistic background of 1 Corinthians 7. New York: Cambridge University Press.

Dibelius, M 1953. Paul. (Edited and completed by W.G. Kümmel. Transl. by F. Clarke). London: Longmans.

Dunn, J D G 2003. The theology of Paul the apostle. London: T\&T Clark.

Du Toit, A B 1984a. Chronology van Paulus, in du Toit 1984b:23-40. (ed.) 1984b. Die Pauliniese briewe: inleiding en teologie. Pretoria: N.G. Kerkboekhandel.

Ewald, G H A 1826. Das Hohelied Salomos übersetzt mit Einleitung, Anmerkungen und linem Anhang über den Prediger. Available:

http://books.google.co.za/books?hl=en\&lr=\&id=UJtXAAAAcAAJ\&oi=fnd\&pg=PA1\& $\mathrm{dq}=$ Das + Hohelied + Salomos $+\% \mathrm{C} 3 \%$ BCbersetzt+mit+Einleitung\&ots=vQ26PsFfYc \&si

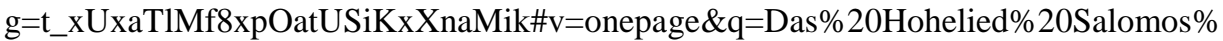
20\%C3\%BCbersetzt\%20mit\%20Einleitung\&f=false. [Accessed 2014//05/09.]

Exum, J C 1973. A literary and structural analysis of the Song of Songs, Zeitschrift für die alttestamentliche Wissenschaft 85:47-79.

2005. Song of Songs: a commentary. Louiseville: Westminster John Knox Press.

Fee, G D 1987. The First Epistle to the Corinthians. Grand Rapids: Eerdmans.

Fields, W W 1980. Early and Medieval Jewish Interpretation of the Song of Songs, Grace Theological Journal 1:221-231.

Fisher, N R E 1992. Hybris: A study in the values of honour and shame in ancient Greece. Warminster: Aris \& Phillips.

Foucault, M 1985. The history of sexuality. Vol. 2. Translated by R. Hurley. New York: Pantheon.

Fox, M V 1985. The Song of Songs and the ancient Egyptian love songs. Madison: University of Wisconsin Press.

Fredrickson, D E 2003. Passionless sex in 1 Thessalonians 4:4-5, Word \& World 23/1:23-30.

Freiberg, T, Freiberg, B and Miller, N F 2000. Analytical lexicon of the Greek New Testament. Vol. 4. Grand Rapids: Baker Books.

Garrett, D A 1993. Proverbs, Ecclesiastes, Song of Songs. New American Commentary. Nashville: Broadman \& Holman.

Garland, D E 2003. 1 Corinthians. Grand Rapids: Baker Academic.

Gollwitzer, H H 1979. Song of love: a biblical understanding of sex. Philadelphia: Fortress Press.

Gravrock, M 1996. Why don't Paul just say no? Purity and sex in 1 Corinthians 6, Word \& World 16/4:444-455.

Green, G L 2002. The letters to the Thessalonians. Grand Rapids: Eerdmans.

Hengel, M 1992. The pre-Christian Paul, in Lieu, North and Rajak 1992:29-52. 2002. The Septuagint as Christian scripture: its prehistory and the problem of its canon. (Martin Hengel, with the assistance of Roland Deines). Edinburg: T\&T Clark.

Hess, R.S. 2005. Song of Songs: not just a dirty book, Bas Library 21/5:n.p. Available: http://members.bib-arch.org/publication.asp?PubID=BSBR \&Volume=21\&Issue $=5 \&$ ArticleID=6. [Accessed 2014/05/12.] 2005. Song of Songs. Grand Rapids: Baker Academic.

Houdman, S M 2014. Was the apostle Paul married? Got questions.org. Available: http://www.gotquestions.org/apostle-Paul-married.html. [Accessed 2014/06/11.]

Jamieson, R, Fausset, A R and Brown, D 1997. Commentary critical and explanatory on the 
whole Bible. Oak Harbor: Logos Research Systems.

Jensen, J 1978. Does porneia mean fornication: a critique of Bruce Malina, Novum Testamentum 20/3:161-184.

Jobes, K H 2000. Invitation to the Septuagint. Grand Rapids: Baker Academic.

Kistemaker, S J and Hendriksen, W 1953-2001. Exposition of the First Epistle to the Corinthians. Grand Rapids: Baker Book House.

LaCoque, A 2006. Romance she Wrote: A Hermeneutical Essay on the Song of Songs. Harrisburg: Trinity Press International. Available https://books.google.co.za/books?id=24dLAwAAQBAJ\&printsec=frontcover\&dq=Rom ance + she + Wrote + A + Hermeneutical + Essay + on + the + Song + of + Songs \&hl $=$ en \&sa $=X \& v$ ed=0ahUKEwiK_8ym8J3OAhUnCcAKHSuBA64Q6wEIHTAA\#v=onepage\&q=Roma nce $\% 20$ she $\% 20$ Wrote $\% 3 \mathrm{~A} \% 20 \mathrm{~A} \% 20$ Hermeneutical\%20Essay\%20on $\% 20$ the $\% 20$ Song $\% 20$ of\%20Songs\&f=false. [Access 2016/07/31].

Lieu, J, North, J and Rajak, T (eds) 1992. The Jews among pagans and Christians: in the Roman Empire. New York: Routledge.

Linnemewyer, J D 2014. Song of Songs structural analysis. Available: Song_of_ Songs_paper.pdf. [Accessed 2014/06/11.]

Longman, T 2001. Song of Songs. Eerdmans: Grand Rapids.

Louw, J P and Nida, E A 1996. Greek-English lexicon of the New Testament: based on semantic domains. Vol. 1. New York: United Bible Societies.

Malina, B J 1972. Does porneia mean fornication?, Novum Testamentum 14/1:10-17.

Marchal, J A 2011. The usefulness of an Onesimus: the sexual use of slaves and Paul's letter to Philemon, Journal of Biblical Literature 130/4:749-770.

McCurley, F R 1983. Ancient myths and biblical faith: scriptural transformations. Philadelphia: Fortress Press.

Miller, J E 2000. Sexual offences in Genesis, Journal for the Study of the Old Testament 90:41-53.

Molvaer, R K 2004. St. Paul's views on sex according to 1 Corinthians 7:9 \& 36-38, Studia Theologica 58/1:45-59.

Mounce, R H 1995. Romans. Nashville: Broadman \& Holman Publishers.

Murphy, D 2014. Sexual symbols in the Song of Songs. Available: http://maranatha life.com/teach-ot/cantares.htm. [Accessed 2014/04/21.]

Murphy, R E 1979. The unity of the Song of Songs, Vetus Testamentum 29/4:436-443.

Ndoga, S S and Viviers, H 2000. Is the woman in the Song really that free?, HTS Theological Studies 56/4:1286-1307.

Nee, W 2011. Song of Songs. Unveiling the mystery of passionate intimacy with Christ. Washington: CLC Publications.

New Life Community Church. Available: http://www.new-life.net/growth/ marriage/sexualallusions-and-symbols-in-the-song-of-songs/:1-8. [Accessed 2014/04/21.]

Newman, B M and Nida, E A 1973. A handbook on Paul's letter to the Romans. New York: United Bible Societies.

Ogden, G S and Zogbo, L 1998. A handbook on the Song of Songs. New York: United Bible Societies.

Pope, M 1977. Song of Songs. New York: Doubleday.

Robinson, A B 2004. Singing of sex: rereading the Song of Songs, Christian Century 121/2:12.

Rosner, B S 1994. Paul, scripture \& ethics. A study of 1 Corinthians 5-7. Leiden: Brill. Available: http://books.google.co.za/books?id=CLjh8ynKYgkC\&printsec=front cover\&dq=Paul,+scripture+and+ethics, + Rosner\&hl=en\&sa=X\&ei=If5xU6inMsmB7Qa 
P54D4CA\&redir_esc=y\#v=onepage $\& \mathrm{q}=\mathrm{Paul} \% 2 \mathrm{C} \% 20$ scripture $\% 20$ and $\% 20$ ethics $\% 2 \mathrm{C}$ \%20Rosner\&f=false. [Accessed 2014/05/20.].

Schnelle, U 2003. Apostle Paul: his life and theology. Transl. by M E Boring. Grand Rapids: Baker Academic.

Schweitzer, S J 2008. Biblical perspectives on sexuality, Vision 9/2:3-24.

2010. Biblical sexual ethics: a survey and starting points, Brethren Life and Thought 55/1-2:1-9.

Schreiner, T R 1998. Romans. Grand Rapids: Baker Books.

Sparks, K 2008. The Song of Songs: wisdom for young Jewish women, Catholic Biblical Quarterly 70/2:277-299.

Tanner, J P 1997a. The history of interpretation of the Song of Songs, Bibliotheca Sacra 154:23-46.

1997b. The message of the Song of Songs, Bibliotheca Sacra 154:142-161.

Thiselton, A C 2000. The First Epistle to the Corinthians: a commentary on the Greek text. Grand Rapids: Eerdmans.

Van der Merwe, D G (forthcoming). Erotic fantasy, spirituality and Song of Songs, Verbum et Ecclesia (forthcoming).

Vinatieri, T 2014. Sexual allusions and symbols in the Song of Songs. Available: http://www.new-life.net/growth/marriage/sexual-allusions-and-symbols-in-the-song-ofsongs/. [Accessed 2014/05/03]

Wanamaker, C A 1990. The epistles to the Thessalonians. A commentary of the Greek text. Grand Rapids: Eerdmans.

Wolf, C U 1948. Concerning the vocabulary of Paul, Journal of Biblical Literature 67/4:331338.

Young, F 2001. Sexuality and devotion: mystical readings of the Song of Songs, Theology and Sexuality 14:80-96.

Zodhiates, S 2000. The complete word study dictionary: New Testament. Chattanooga: AMG Publishers. 